\title{
PENGEMBANGAN PRODUK LIFESTYLE BERFITUR MENGHIBUR DENGAN TEKNOLOGI CNC BAGI KOMUNITAS KREATIF CIREBON
}

\author{
Deny Willy Junaidy', Linda Mawali², Siti Sa'adah ${ }^{3}$, \\ Samuel Aswin Moeljanto ${ }^{4}$, Sarif Gunawan ${ }^{5}$ \\ 1KK Manusia dan Ruang Interior FSRD, Institut Teknologi Bandung \\ 2,3Program Studi Magister Desain FSRD, Institut Teknologi Bandung \\ ${ }^{4}$ EastWood Rubber Gun \\ ${ }^{5}$ ARLI Fashion Craft \\ Email : 1denywilly@itb.ac.id
}

\begin{abstract}
Abstrak
Kegiatan Pengabdian kepada Masyarakat pengembangan produk gaya hidup dengan fitur menghibur berbasis teknologi CNC bagi komunitas kreatif Cirebon melibatkan akademisi, desainer-pengusaha, aktivis desa, serta mahasiswa Merdeka Belajar dan Kampus Merdeka (MBKM). Pelatihan berlangsung selama enam bulan dan telah menghasilkan output berupa produk dan skill, serta metode-metode pengembangan produk, serta pengenalan pasar. Proses pengembangan produk menekankan pemanfaatan teknologi Computer Numeric Control (CNC). Teknologi Computer Numeric Control (CNC), khususnya untuk pemotongan bahan dan pembuatan kontur tiga dimensional. Hasil akhir pelatihan adalah lima tas kulit dengan dengan fitur baru mekanik pengunci dari logam dan kayu yang memberikan efek menghibur dan dapat dimainkan oleh pengguna. Kelima produk tersebut telah terdaftar Hak Desain Industri-nya pada Direktorat Jenderal Kekayaan Intelektual (DJKI).
\end{abstract}

Kata Kunci: CNC; tas kulit; fitur menghibur; industri kreatif, Cirebon

\begin{abstract}
We conducted a community service activities to enhance existing product to some new design and new feature of leather products. The enhancement applied entertaining features such as a mechanic-based interlocking system that strengthen the appearances and experience of users. The entertaining feature is to create a contemporary lifestyle products experience. The production process utilised CNC technology to meet theproduction capacity of the demand of this lifestyle leather bag produced by hone industries. The training involed academicians, design-entrepreneurs, Cirebon creative community, local village activists, as well as students of Merdeka Belajar and Merdeka Campus (MBKM). The training lasts for six months and has produced a number of new feature of leather bags, participants gained their skills, new methods of product development, as well as market recognition. The product development process emphasizes the utilization of Computer Numeric Control (CNC) technology. Computer Numeric Control (CNC) technology, specifically for cutting materials, manufacturing three-dimensional contours that includes for hole stiching. The final result of the training is five leather bags with mechanic-based interlocking system by means of metal and wood with entertaining effect that can be played by the users. The five products have been registered for the Industrial Design Rights with the Directorate General of Intellectual Property (DJKI).
\end{abstract}

Keywords : CNC, leather bag, entertainig-feature; creative industry, Cirebon 


\section{PENDAHULUAN}

Cirebon merupakan salah satu wilayah yang memiliki peninggalan produk kriya yang cukup dikenal di Indonesia, antara lain batik (trusmi), gerabah serta anyaman rotan. Masyarakat di wilayah ini sudah memiliki keahlian tersebut berasal dari generasi-generasi sebelumnya. Sehingga dapat dikatakan bahwa keahlian ini sudah menjadi budaya bagi masyarakat di sebagian wilayah di Cirebon. Upaya pelestarian perlu dilakukan dalam upaya menjaga kelangsungan sebuah budaya yang telah menjadi identitas bagi masyarakat di wilayah tersebut.

Dalam upaya melestarikan keahlian dalam bidang kerajinan tersebut, tantangan yang paling nyata adalah berkurangnya minat generasi muda terhadap kerajinan dan untuk memiliki keahlian teknis tentang kerajinan tersebut. Ini hampir berlaku di setiap produk kerajinan, sehingga perlu tindakan nyata untuk bisa mempertahankan keberadaan produk kerajinan di wilayah ini. Perubahan pola pengerjaan produk kerajinan dari yang sebelumnya hanya mengandalkan keahlian tangan (fully handmade) menjadi berorientasi teknologi dan mekanisasi merupakan salah satu upaya untuk menjadikan daerah ini tetap terjaga sebagai basis produksi kerajinan untuk memenuhi kebutuhan ekonomi masyarakat yang sebelumnya banyak bergantung pada industri kerajinan. Selaras dengan ekonomi kreatif, industri kerajinan sebagai salah satu subsektor industri kreatif, seperti yang terdefinisikan oleh Badan Ekonomi Kreatif Indonesia dalam Konfrensi Ekonomi Kreatif Dunia tahun 2018 yang disampaikan oleh Parrish (2019), "Ekonomi kreatif keberadaannya dapat menciptakan menciptakan nilai tambah berbasis kreativitas yang dilindungi oleh hak cipta, dan berasal dari warisan budaya, pengetahuan dan teknologi.". Sehingga industri kreatif memiliki peran penting dalam pelestarian budaya dan pengembangan sektor ekonomi di masyarakat. Merujuk pernyataan dari Irena Silinevica, dkk (2016), "Pengembangan produk baru adalah salah satu faktor kunci untuk kemajuan dan keunggulan kompetitif di setiap negara." Hal ini selaras dengan pendapat yang dikemukakan oleh Fontana (2009) menyatakan bahwa inovasi adalah keberhasilan ekonomi karena kombinasi atau cara baru untuk menggantikan cara lama mengubah input menjadi output yang dapat menghasilkan perubahan substansial dalam rasio nilai guna yang dirasakan oleh konsumen atau dapat disebut manfaat suatu produk dengan harga yang ditetapkan oleh produsen. Zahra, dkk (1999) juga menyatakan bahwa, Inovasi ditandai sebagai proses yang mengubah ide menjadi produk atau produk yang berharga untuk mendapatkan keunggulan kompetitif keuntungan di pasar. Sehingga, dalam menjaga usaha yang berkelanjutan, perlu adanya inovasi-inovasi yang dilakukan. Inovasi yang dapat dilakukan dapat berupa pengembanan produk dengan menciptakan kebaruan desain, inovasi material, maupun kebaruan dalam metode eksekusi.

Dengan sumber daya manusia yang ditunjang dengan kemampuan kreatif, usaha kerajinan di Cirebon bisa berkembang lebih besar lagi. Di Cirebon, tepatnya Desa Karangmulya, Plumbon, terdapat salah satu badan usaha mikro yang memproduksi tas kulit. Produk dengan bahan baku kulit sapi asli sebenarnya dapat menjadi industri dengan skala besar, menurut Data Badan Pusat Statistik oleh Hidayat \& Susilowati (2016), peningkatan permintaan di dalam negeri terhadap produk olahan kulit termasuk tas kulit mencapai 20-30 persen tiap tahunnya. Walaupun banyak tas kulit imitasi yang beredar di pasar, namun tas kulit asli mempunyai pangsa pasar sendiri dan semakin banyak peminatnya. Sehingga omset yang didapatkan oleh usaha kerajinan kulit sangatlah besar. Namun, dalam pengembangan tren produk dan berkembangnya gaya hidup masyarakat, diperlukan kolaborasi antara kerajinan tradisional kulit dengan teknologi yang tengah berkembang saat ini untuk memenuhi kebutuhan pasar dan juga bersaing di dunia industri kreatif. Kendala yang sering dihadapi oleh industri dengan eksekusi produk secara manual oleh manusia adalah sering terjadinya human error yang berdampak pada kecepatan produksi dan pemenuhan omset.

Dalam menjawab tantangan omset pasar dan mereduksi kesalahan produksi teknologi Computer Numeric Control (CNC) dapat membantu produksi usaha level mikro sampai makro. CNC merupakan mesin automasi yang dioperasikan menggunakan 
perangkat keras dan lunak komputer. Salah satu kegunaan dari CNC ini adalah dalam pengembangan dan percepatan proses produksi. Mesin CNC dapat menjamin akurasi dan konsistensi produksi, meskipun produksi bersifat massal. Dengan teknologi CNC, pergantian produksi produk dengan desain yang berbeda menjadi sangat mudah, karena berdasarkan sistem komputasi (Mike Lynch, 1997). Sistem CNC melakukan semua perhitungan yang berkaitan untuk menggeser gerakan, mengontrol pengoperasian penggerak utama dan penggerak umpan sumbu, menciptakan alfanumerik dan grafik pada perangkat tampilan, mengelola antarmuka operator seperti alarm pesan dan mengontrol operasi pengontrol logika yang dapat diprogram (Radhakrishnan, 2014).

Mesin-mesin CNC dibangun untuk menjawab tantangan di dunia manufaktur modern. Dengan mesin $\mathrm{CNC}$, pengerjaan produk massal dengan hasil yang sama persis dan waktu permesinan yang cepat. Dalam kaitan pengembangan produk kerajinan menuntut diperlukannya tenaga terampil, penyediaan tenaga pengrajin lambat laun akan menjadi semakin langka, karena kurangnya minat orang untuk mempelajari keahlian kerajinan. Sehingga diharapkan mesin CNC ini dapat dijadikan salah satu alternatif jalan keluar untuk menyelesaikan persoalan lambatnya pengembangan produk kerajinan ini.

Selain itu pemanfaatan CNC sangat tepat pada proses pengembangan produk dengan bahan-bahan semi lunak, menurut Marius, dkk (2018), untuk membuat pemotongan dua atau tiga dimensi, diperlukan alat otomatis khusus sehingga memungkinkan untuk mempercepat proses pemotongan bahan sekaligus meningkatkan presisi dari proses buatan yang sama. Salah satu alat yang digunakan untuk memotong bahan lunak, seperti kayu, PVC atau bahan non-metal tertentu, adalah router $\mathrm{CNC}$.

Keberadaan Akademis dalam membatu pengembangan produk kerajinan juga sangat diperlukan, baik kaitannya dengan peningkatan kemampuan penggunaan mesin hingga pengembangan desain terapannya. Sehingga diharapkan akan terjadi kolaborasi dari berbagai elemen, baik dari pelaku kerajinan itu sendiri, pihak pemerintah dalam hal ini Dinas Perdagangan dan Perindustrian Kab. Cirebon dan ITB.
Pengabdian masyarakat ini berlangsung selama enam bulan dengan melibatkan komunitas kreatif muda Cirebon dari berbagai macam latar belakang yang berbeda. Pengabdian masyarakat ini dilakukan melalui workshop yang dipandu langsung oleh narasumber dengan latar belakang sebagai pengusaha produk berbasis kulit dan $\mathrm{CNC}$, serta akademisi di bidang desain. Workshop pengembangan produk dilaksanakan secara komunikatif, privat, dengan jumlah peserta yang terbatas dan menggunakan metode design thinking. Design thinking merupakan proses memahami kebutuhan manusia yang terkait dengan suatu masalah, membingkai ulang masalah dengan cara yang berpusat pada manusia, menciptakan banyak ide dalam sesi brainstorming, dan mengadopsi pendekatan langsung untuk pembuatan prototype dan pengujian-menawarkan pendekatan pelengkap untuk metode pemecahan masalah rasional (Foster, 2019). Metode design thinking mampu membantu proses penciptaan produk yang memiliki keunikan dengan merespons kondisi yang beragam (Nagaraj, 2020). Proses design thinking meliputi (1) Information gathering; (2) Problem analysis; (3) Idea generation; (4) Synthesis through modelling; dan (5) Critical evaluation (Pressman, 2018).

\section{METODE PELAKSANAAN}

Program pengembangan produk dalam rangka pengabdian masyarakat ini menggunakan metode design thinking. Pengabdian masyarakat ini diselenggarakan di Warehouse ARLI Fashion Craft yang beralamat di Jl. Prapatan 124 Karangmulya, Plumbon Cirebon. Masyarakat yang terlibat dalam proses pengembangan produk di Warehouse ARLI Fashion Craft adalah sebanyak dua puluh orang. Selama kurang lebih tiga bulan sebelum pelatihan dan pengembangan desain produk dilakukan kami memikirkan dan merancang hal-hal yang menyangkut kegiatan dari awal hingga akhir. Mulai dari planning kegiatan, ideasi produk, pembuatan desain produk, hingga pelatihan dan pengembangan produk langsung di lapangan. Melalui diskusi panjang dan koordinasi dalam chat grup WhatsApp kami mengatur strategi yang tepat dan matang sehingga proses kegiatan dapat dieksekusi dengan baik.

Koordinasi dimulai dengan mengatur rencana kegiatan yang akan dilakukan, hal ini terus 
berproses sejak koordinasi berlangsung hingga menjelang kegiatan acara dimulai. Selanjutnya proses deisgn thinking dimulai dengan tahapan information gathering atau emphasize yakni mengumpulkan informasi terkait permasalahan produk dan pasar, kemudian dilanjut dengan proses problem analysis dengan memikirkan produk yang akan diproduksi dan memikirkan impact dari produk dengan pertimbangan studi niche market. Pada dasarnya pemasaran relung (niche marketing) adalah strategi pemasaran yang pemilihan pasarnya ditujukan kepada pasar yang lebih sempit yang disebut relung, dengan demikian alat-alat promosi pada pemasaran relung termasuk praktis tidak berbeda dengan pemain di pasar mainstream (utama) (Situmorang, 2017). Hal ini selaras dengan penelitian yang dilakukan oleh Dalgic (1998) bahwa, Niche market berfokus pada pelanggan, pesaing berorientasi, responsif, antisipatif, dan keseimbangan fungsi antara pasar dan sumber daya internal. Selain itu, niche market jalur pemasaran bisnis yang ditargetkan peluang dan hubungan jangka panjang untuk mempertahankan dan mempertahankan profitabilitas.

Setelah dilakukan problem analysis dan diskusi. Pada tahapan ideasi umum diputuskan bahwa produk yang dibuat adalah produk tas berbahan dasar kulit dengan inovasi pengunci mekanik dari kuningan dan kayu sungkai. Selanjutnya mendiskusikan jenis tas yang akan dibuat dengan baik dan berakhir di proses ideasi atau desain. Jenis tas yang dibuat terdiri dari massanger bag dan sling bag untuk pria dan wanita. Tas ini dapat digunakan untuk kesempatan santai atau semi formal. Selanjutnya pada proses desain yang berlangsung secara bertahap menghasilkan sedikitnya dua puluh buah sketsa desain tas dengan berbagai model, sepuluh buah sketsa desain pengunci mekanik dengan berbagai model dan tujuh buah sketsa desain hampers dengan berbagai model. Desain-desain yang dibuat sangat inovatif dan unik dengan fitur menghibur, bisa dimainkan dan merupakan penunjang gaya hidup. Dari beragam desain tas dan pengunci mekanik yang ada, kemudian dipilih lima desain terbaik yang pada akhirnya diproduksi.

Langkah selanjutnya dilakukan koordinasi perihal merek produk yang akan digunakan. Sedikitnya ada enam buah nama yang didiskusikan, hingga berakhir pada nama Gunawan yang digunakan sebagai merek produk tersebut. Merek tersebut kemudian dibuat menjadi sebuah logo. Saat merandang desain logo, terdapat sedikitnya Sembilan puluh buah desain sketsa logo dan akhirnya dipilih salah satu desain terbaik.

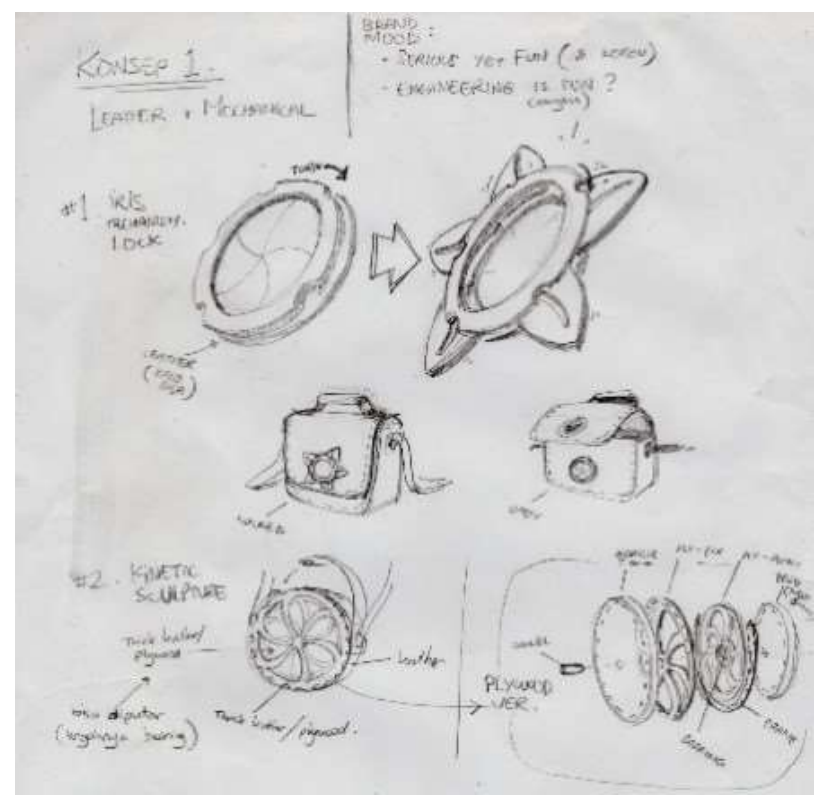

Gambar 1. Desain mekanik dan tas mekanik
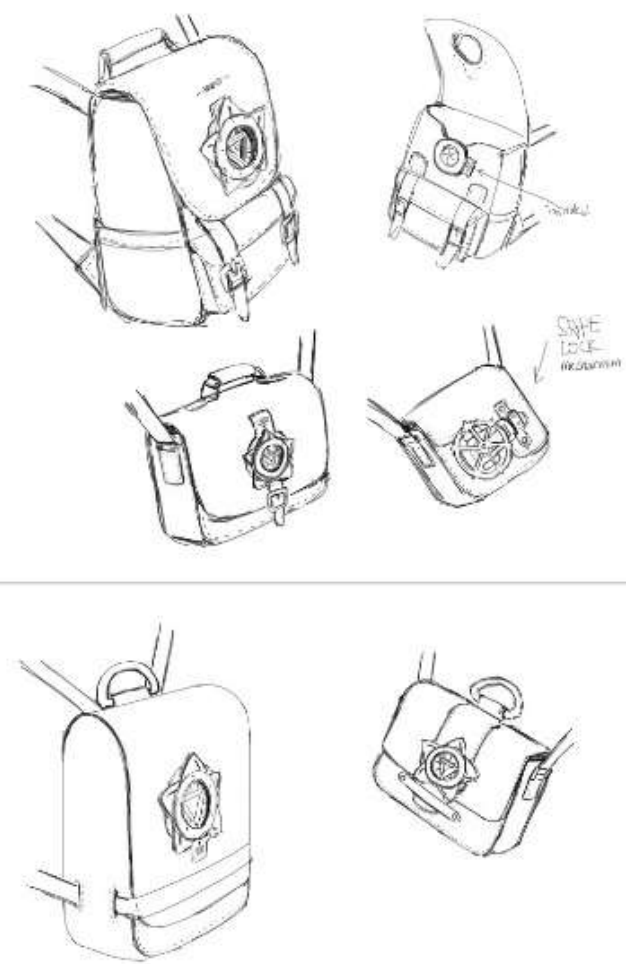

Gambar 2. Desain tas mekanik 


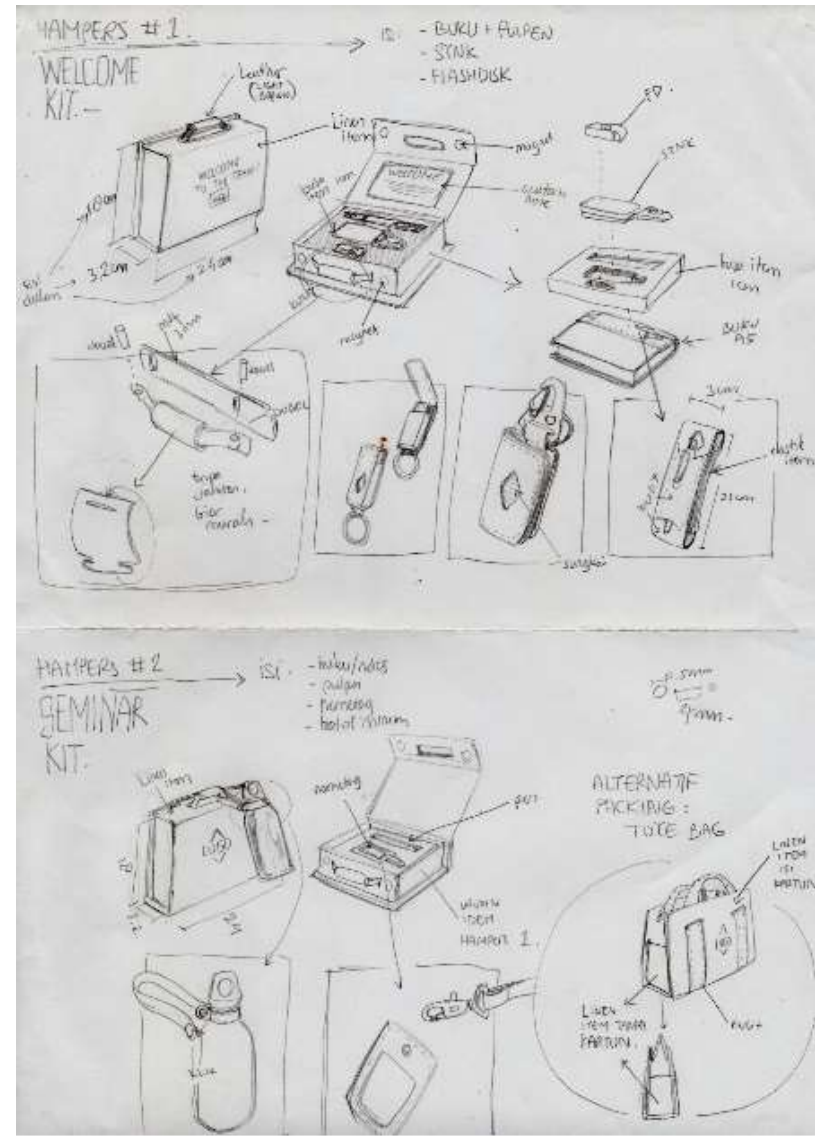

Gambar 3. Desain hampers

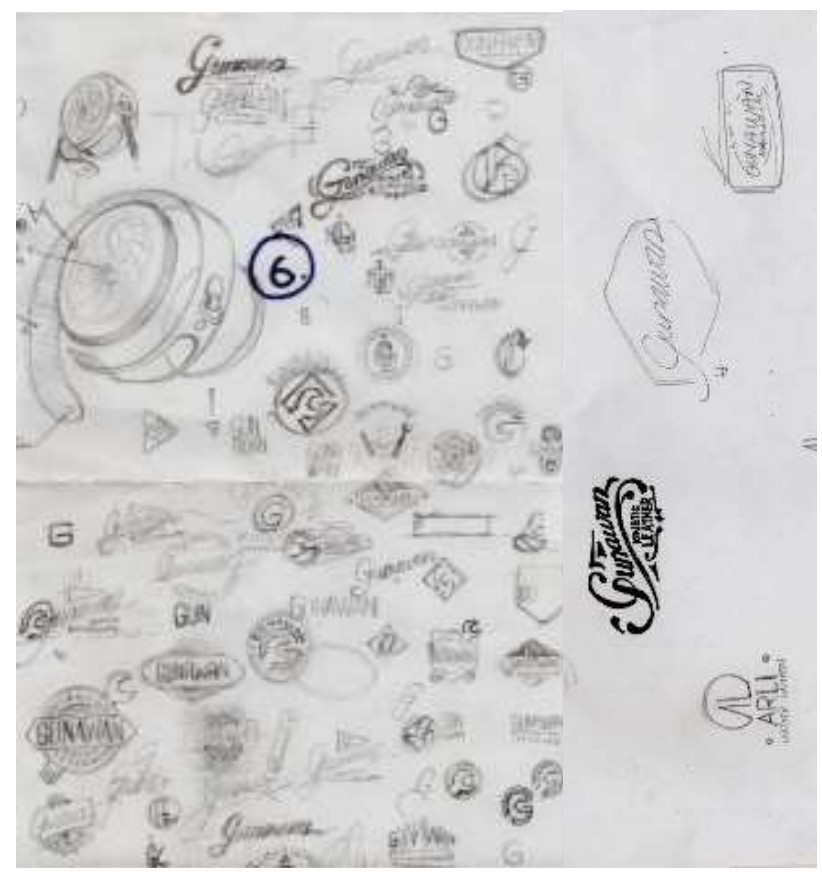

Gambar 4. Rumusan sketsa desian logo

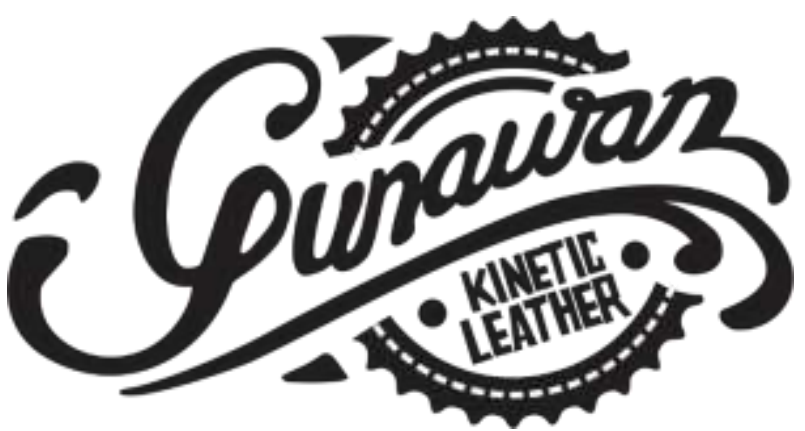

Gambar 5. Desian logo digital Gunawan

Bahan utama yang digunakan dalam pembuatan produk tas mekanik berbahan kulit adalah kulit sapi aseli (leather) dengan ketebalan mulai dari 0,45mm, 1,2mm, 1,4mm hingga 1,6mm. Jenis kulit dan warna yang digunakan diantaranya leather dye color brown, leather dye color tan dan leather dye color yellow. Sedangkan bahan utama untuk aksesoris mekanik pengunci yang digunakan adalah kayu sungkai dan kuningan. Alat utama yang digunakan yaitu mesin CNC Lasser cut dan CNC Router. Adapun alat pendukung lainnya seperti stitching hole punch, groover creasing, gunting, tempered glass $10 \times 13 \mathrm{~cm}$, stick set, wood brunisher for edge, metal buckle $40 \mathrm{~mm}$ dan polisher.

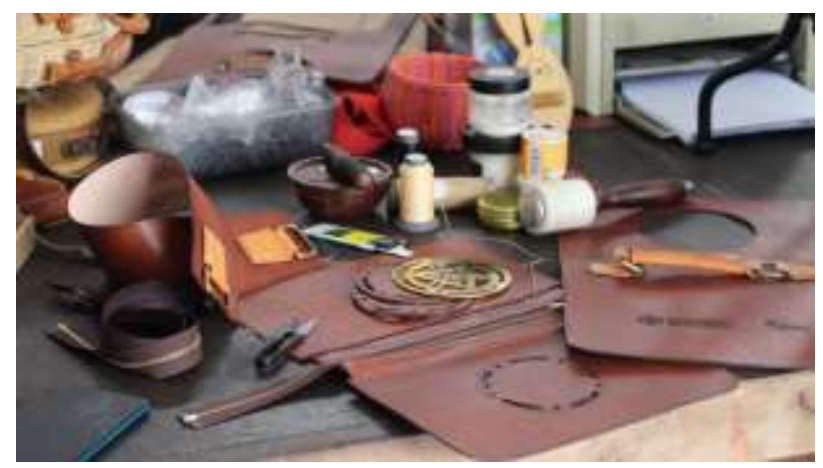

Gambar 6. Alat dan bahan yang digunakan

Setelah proses desain sketsa selesai dan alat dan bahan telah disiapkan, selanjutnya adalah proses sintesa melalui pembuatan dummy model mulai dari pembuatan pola hingga finishing. Berikut ini adalah 
beberapa proses pembuatan tas: (1) membuat pola desain melalui komputer menggunakan software Coreldraw; (2) mempersiapkan bahan kulit yang akan digunakan dan bahan penunjang lainnya; (3) memotong kulit menggunakan mesin laser dengan pola digital yang telah dibuat; (4) membuat aksesoris mekanik dari kayu sungkai dengan memotong pola digital menggunakan mesin $\mathrm{CNC}$ router; (5) menyiapkan aksesoris mekanik kuningan yang telah tersedia; (6) menjahit semua pola kulit yang telah dipotong menggunakan tangan beserta pengunci mekanik atau aksesoris lainnya. Proses pembuatan tas pengunci mekanik dengan fitur menghibur didokumentasikan sebagai berikut:

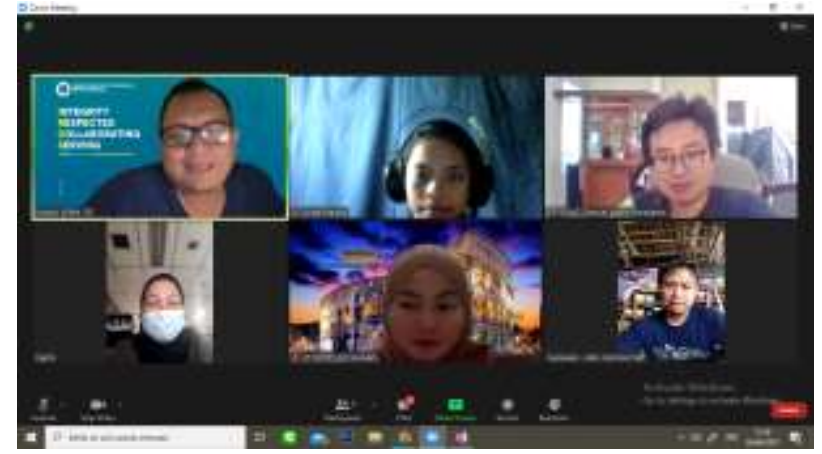

Gambar 7. Dokumentasi diskusi bersama melalui platform digital

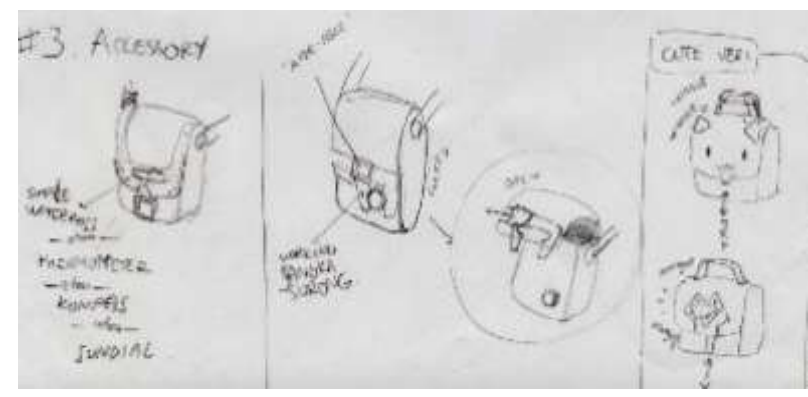

Gambar 8. Proses produksi sketsa desain
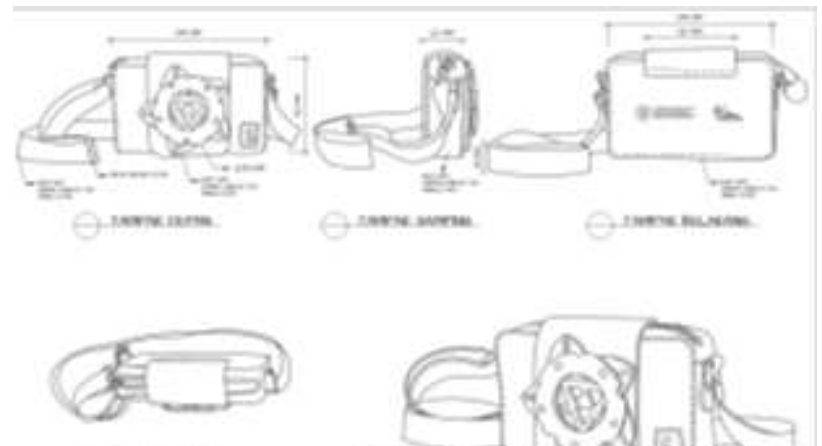

Q introves

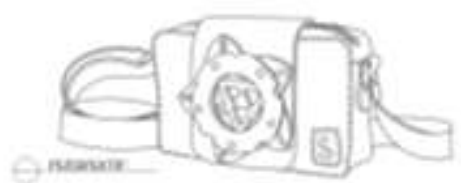

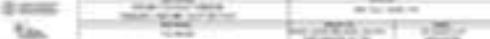

@ Deny Willy Junaidy. et. al

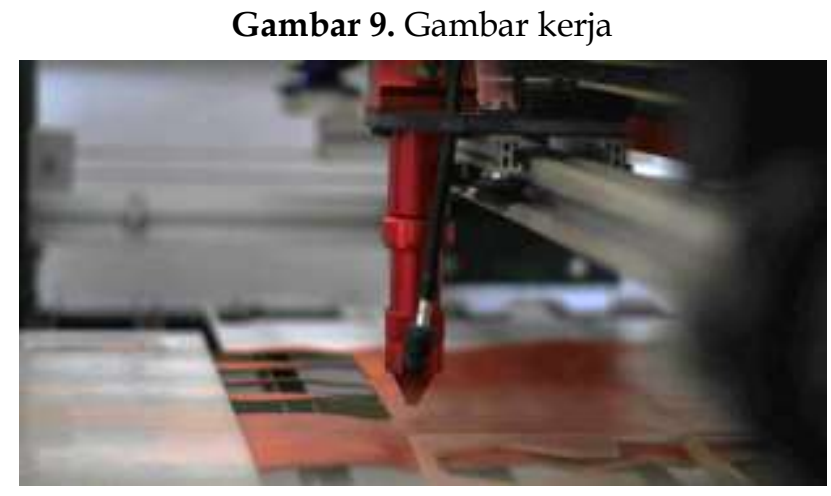

Gambar 10. Proses pembuatan pola menggunakan mesin CNC lasercut

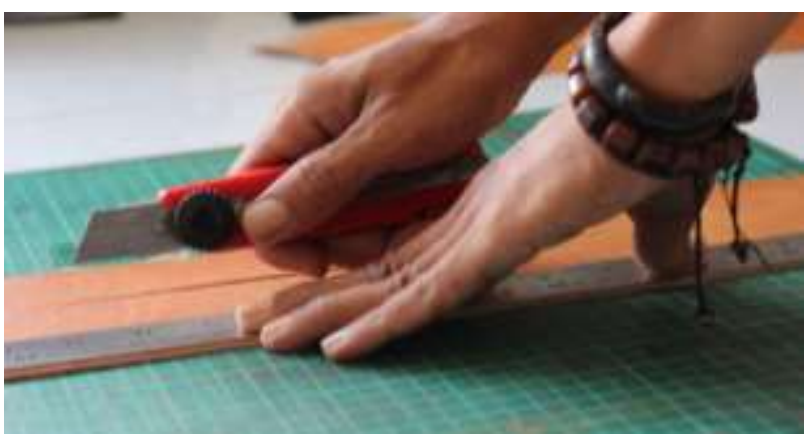

Gambar 11. Proses pemotongan pola penggunakan metode manual

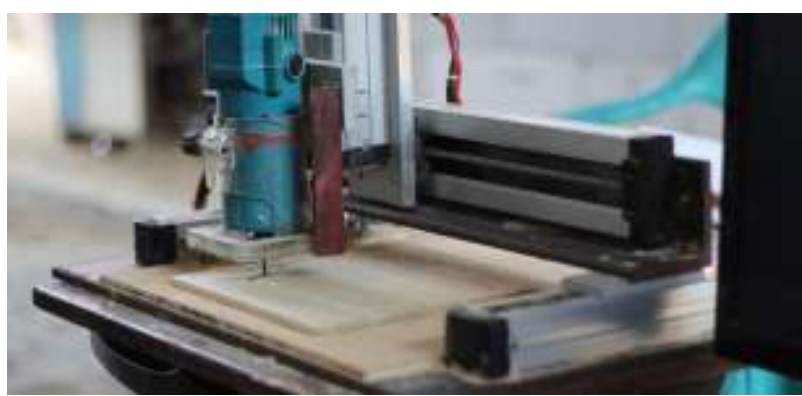

Gambar 12. Pembuatan pola menggunakan mesin $\mathrm{CNC}$ router

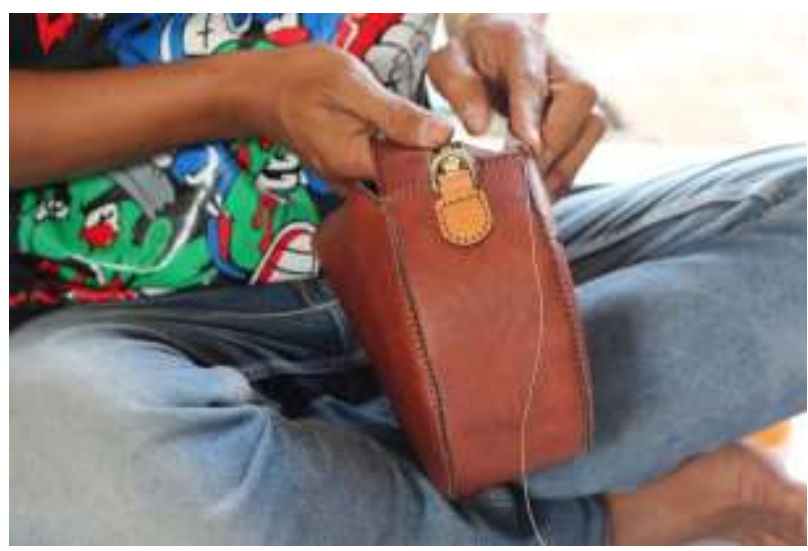

$101 \mid \mathrm{K}$ a i b o n A b h in a y a 
Gambar 13. Proses penyatuan bahan dengan metode jahit tangan

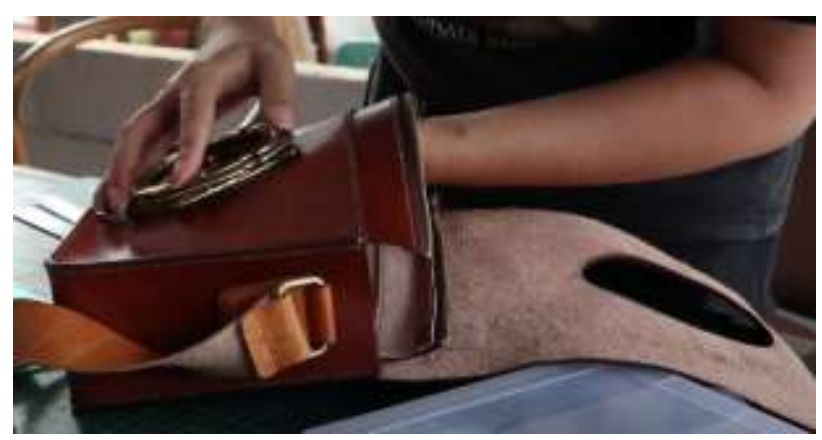

Gambar 14. Proses uji coba mekanika

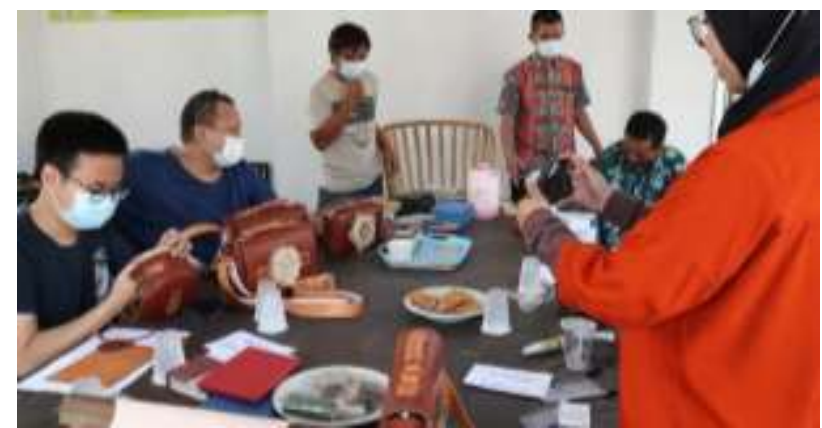

Gambar 15. Proses peliputan pers oleh berbagai media cetak dan digital lokal

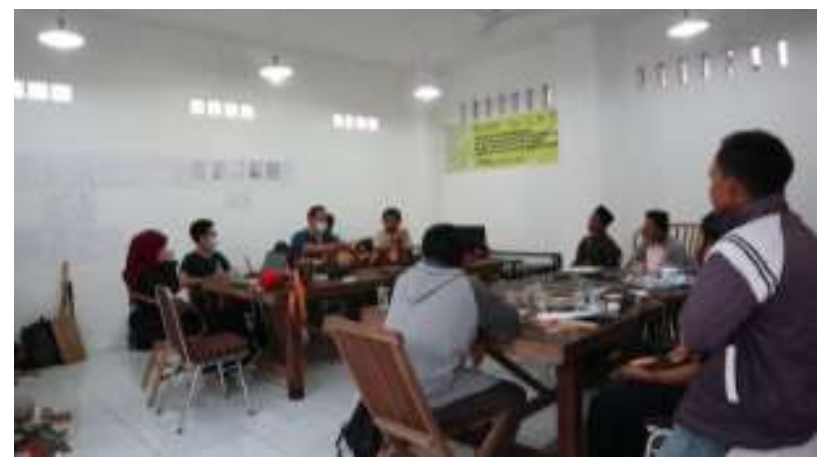

Gambar 16. Proses evaluasi dan penutupan oleh semua pihak yang terlibat

\section{HASIL DAN PEMBAHASAN}

Hasil dari kegiatan pengabdian masyarakat ini yaitu berupa lima desain produk tas dengan bahan baku kulit sapi asli yang diintegrasikan dengan mekanika sederhana fitur menghibur dengan material kayu dan kuningan. Desain didapat dari proses kreatif selama pelatihan, yakni proses ideasi, diskusi, desain, hingga membuat model dan uji coba produk. Dalam proses pembuatan produk, digunakan mesin $\mathrm{CNC}$ lasercut dan $\mathrm{CNC}$ router sebagai alat utama.

\section{Proses Ideasi dan Desain}

Sebelum proses persiapan pengembangan produk, dilakukan riset tentang niche market, tren pasar dan rencana pengembangan produk. Hasil riset mengerucut pada penelitian yang dilakukan oleh Blijlevens (2009), bahwa dengan tren playful things merupakan salah satu hal yang dipersepsi pertama kali dari sebuah produk. Atas hasil riset tersebut diputuskan bahwa pengembangan produk dilakukan dengan mengombinasikan produk tas kulit dengan sistem pengunci mekanika dan fitur menghibur sehingga produk dapat fungsional sekaligus menghibur pengguna. Setelah penentuan ide besar produk, dilakukan proses desain produk dengan pertimbangan hasil riset pasar dan target pasar. Proses desain produk awal menghasilkan lebih dari sepuluh sketsa produk yang kemudian dianalisis kembali dan menghasilkan lima desain produk yang sesuai dengan target pasar dan sesuai dengan ide besar tas kulit dan mekanika sederhana.

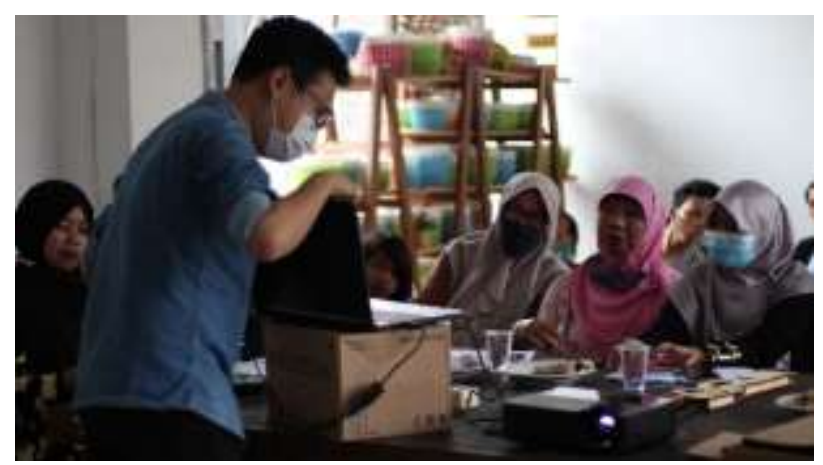

Gambar 17. Pengenalan niche market dan unique selling point (USP) kepada para pelaku usaha

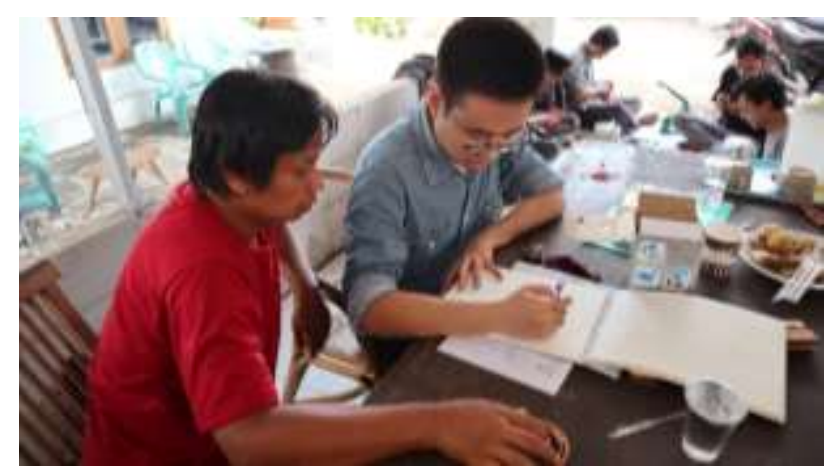

Gambar 18. Proses ideasi dan desain 


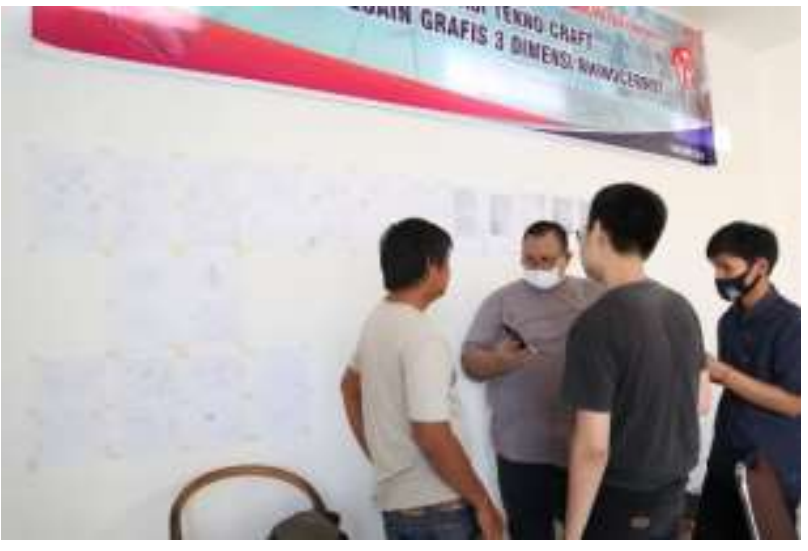

Gambar 19. Proses ideasi dan produksi sketsa desain

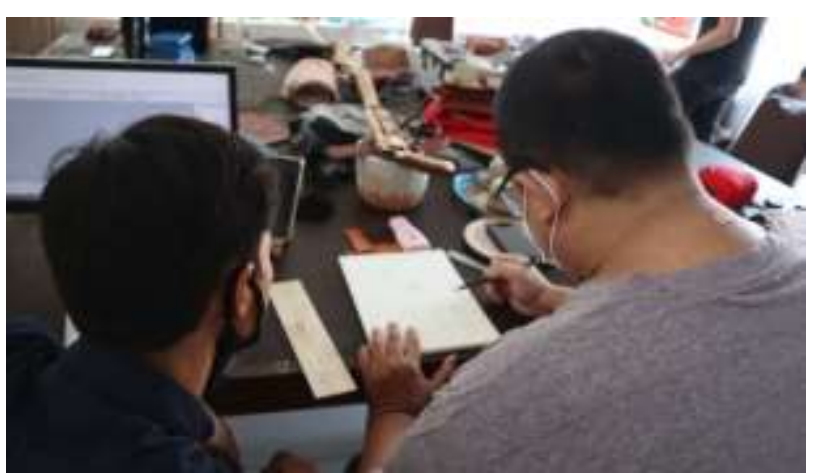

Gambar 20. Proses diskusi digitalisasi Sketsa

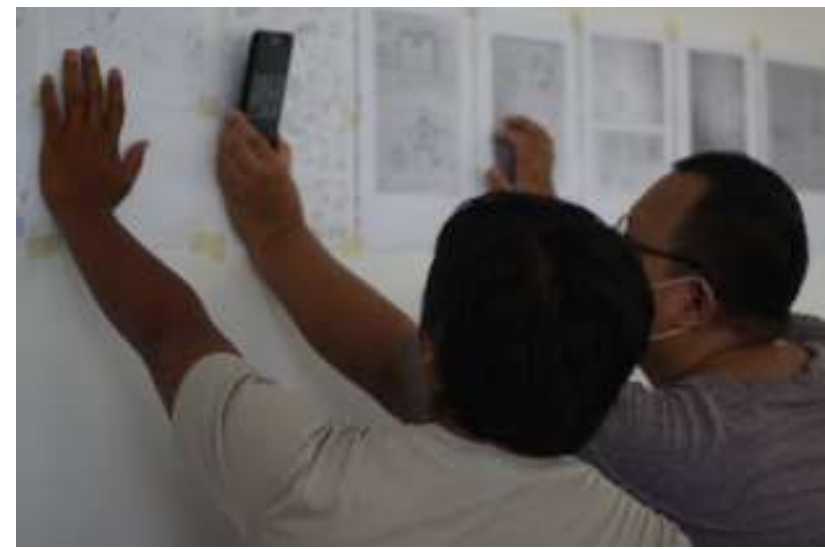

Gambar 21. Proses analisis sketsa desain

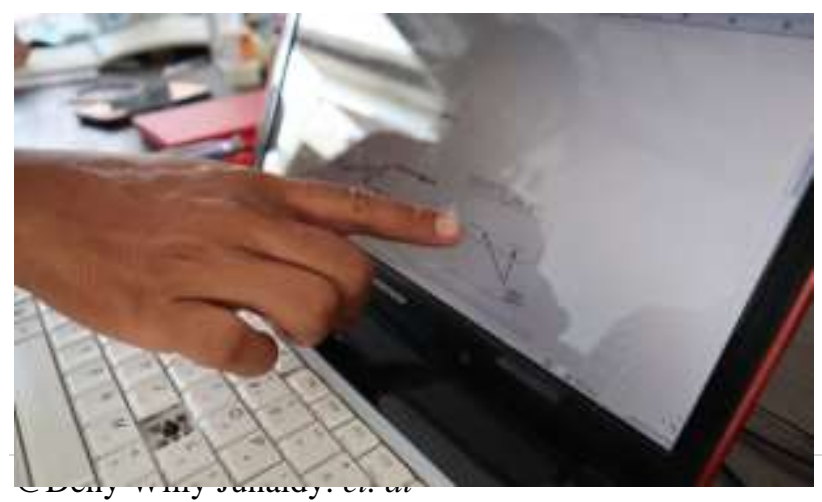

Gambar 22. Proses produksi gambar kerja Setelah desain produk dihasilkan tahap selanjutnya adalah mendesain logo untuk produk-produk tersebut.

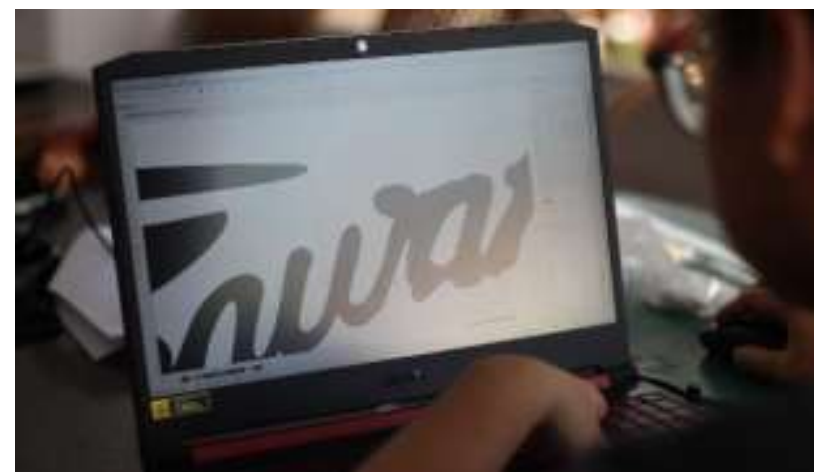

Gambar 23. Proses pembuatan logo digital

Setelah informasi desain produk sudah lengkap, dilakukan produksi dummy model untuk uji coba desain, karena produk ini adalah inovasi baru sehingga diperlukan analisis dummy model untuk pengembangan desain.

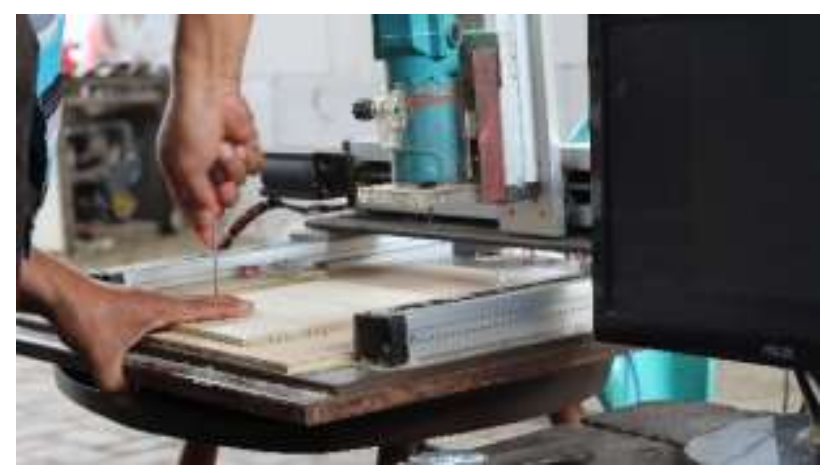

Gambar 24. Proses persiapan penggunaan CNC router

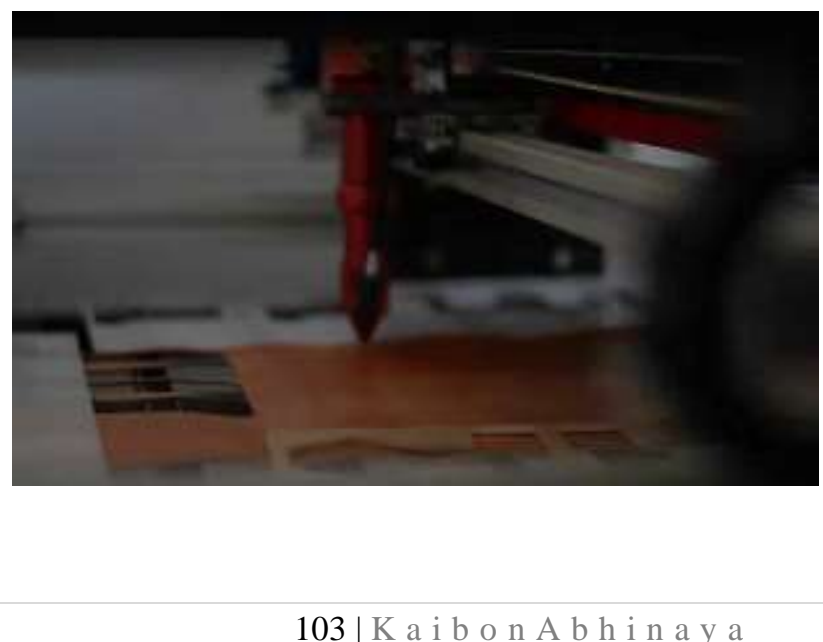


Gambar 25. Proses persiapan pemotongan kulit menggunakan CNC lasercut

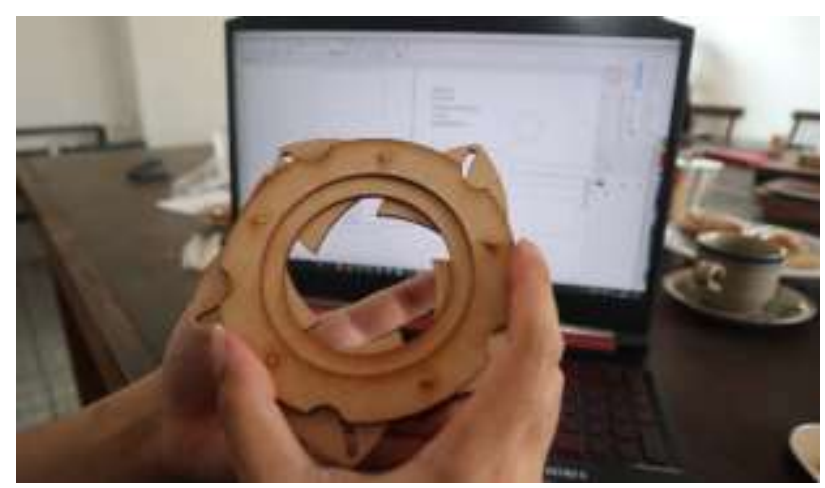

Gambar 26. Proses uji coba hasil CNC router

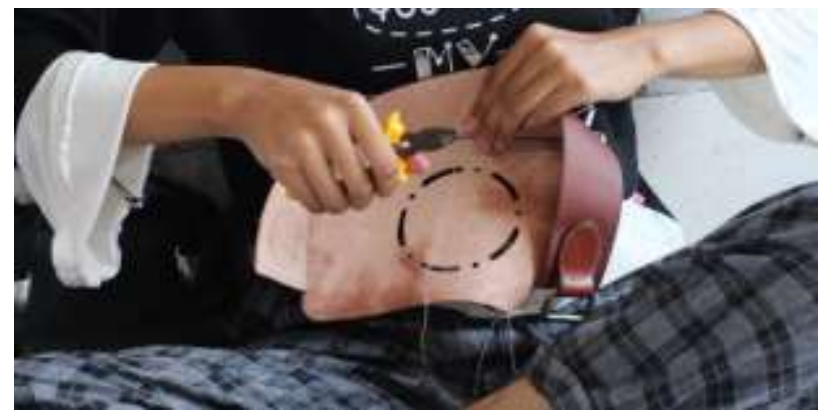

Gambar 27. Proses jahit manual (hand stitch)

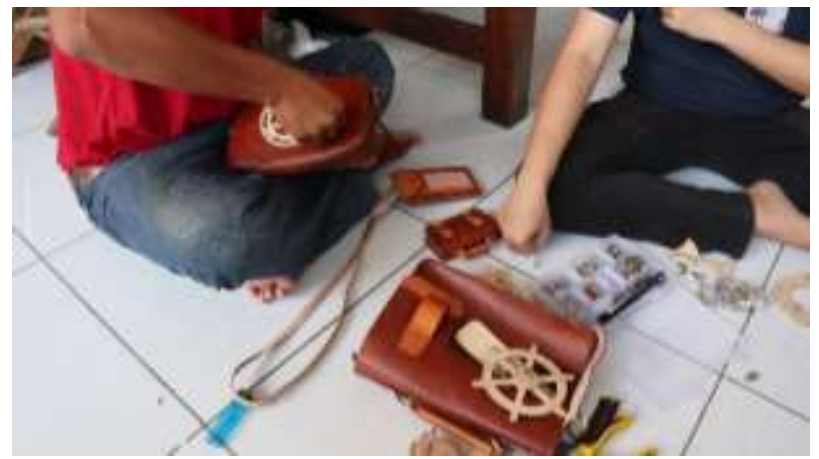

Gambar 28. Proses penyatuan komponen produk

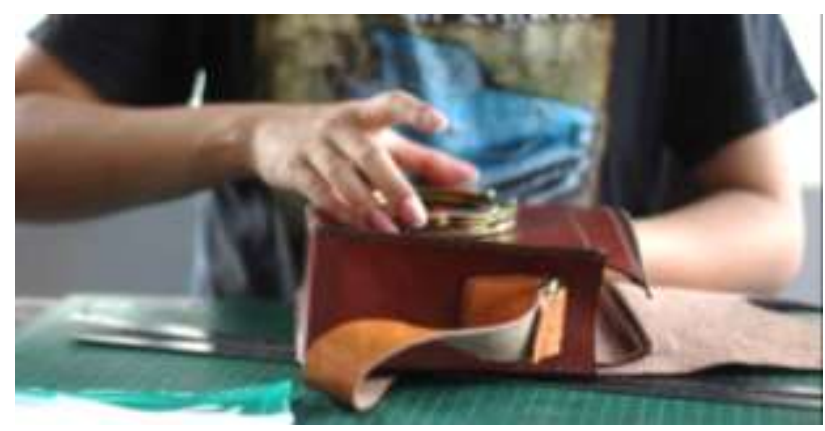

Gambar 29. Proses uji coba dummy model
Proses pengembangan desain dilakukan mulai dari analisis dimensi produk, penyatuan komponen produk, uji gerak mekanika, dan keberhasilan fitur menghibur untuk digunakan. Setelah pengembangan dirasa cukup, maka produk diproduksi kembali.

2. Alat

(1) CNC Lasercut

CNC lasercut merupakan alat utama dalam pembuatan produk tas kulit mekanik ini. Dengan proses desain digital, akurasi yang dihasilkan dari pola digital cukup tinggi. Mesin ini dapat digunakan untuk media potong sampai dengan ketebalan $3 \mathrm{~mm}$. Pada proses pembuatan tas ini, CNC lasercut digunakan untuk memotong pola pada bahan kulit sapi asli dan kayu dengan ketebalan $3 \mathrm{~mm}$.

\section{(2) CNC Router}

Sistem kerja CNC router serupa dengan lasercut yang menggunakan software untuk mengeksekusi desain digital. Perbedannya adalah pada hasil eksekusinya. CNC router menggunakan ujung berupa mata bor, sehingga untuk akurasinya berdasarkan hard tools atau mata bor yang tersedia. Mesin CNC router dapat digunakan pada media potong sampai dengan ketebalan $1 \mathrm{~cm}$. Pada proses produksi produk ini, CNC router digunakan dalam pemotongan material kayu.

(3) Alat Jahit Manual

Added value yang dipertahankan pada usaha kulit ini adalah metode penyatuan komponen bahan dengan menggunakan jahitan tangan. Menurut pemilik usaha pengaplikasian jahit tangan lebih variatif motifnya, ekslusif dan daya ketahanan lebih kuat dibandingkan dengan jahitan mesin. Alat yang digunakan untuk jahit manual ini adalah benang lilin dan jarum besar.

3. Proses Produksi dan Hasil Produksi

(1) Produk tas kulit dengan pengunci mekanik fitur menghibur shutter kuningan

Produk pertama yaitu tas kulit dengan pengunci mekanik shutter kuningan, berbahan dasar kulit dan terdapat pengunci mekanik dibagian muka tas. Produk tas kulit ini berfungsi untuk menyimpan barang dengan fitur pengunci mekanik model shutter yang diputar dan dapat dimainkan sekaligus sebagai aksesoris gaya hidup. Tas ini 
didesain untuk pria dengan model messenger bag berukuran $28 \times 8 \times 17 \mathrm{~cm}$, dengan pegangan dibagian atas tas (handle), berbahan dasar kulit dengan penguncian mekanik model shutter fungsional, berbahan kuningan dengan fitur menghibur/dapat dimainkan. Terdapat satu kantung utama, satu tali selempang, satu pegangan (handle) dan satu pengunci mekanik pada tas tersebut. Adapun komposisi garis dan/atau warna pada tas tersebut yaitu medium brown kombinasi tan, dengan bahan kulit aseli jenis nabati yang dipotong menggunakan CNC lasercut, dengan tampilan depan penguncian mekanik berwarna kuning dengan diameter $11 \mathrm{~cm}$ yang dipotong menggunakan $\mathrm{CNC}$ router. Sedangkan untuk melubangi jahitan (stitch) digunakan lasercut yang kemudian dijahit secara manual.

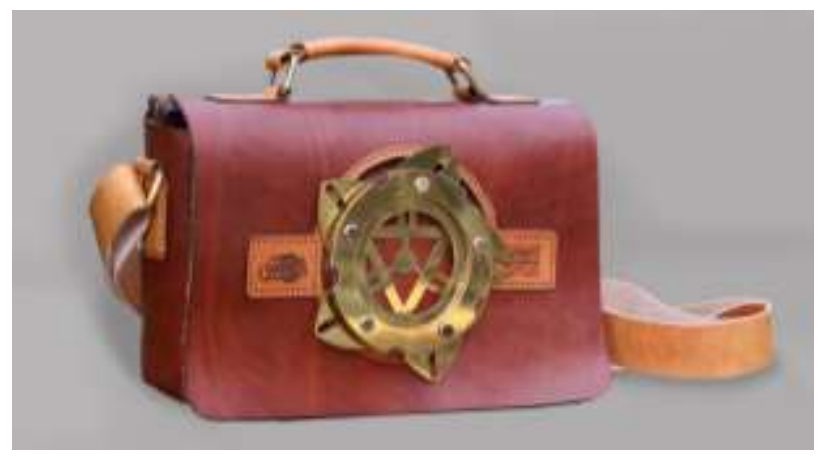

Gambar 30. Produk tas kulit dengan pengunci mekanik fitur menghibur shutter kuningan

Keunggulan produk ini didesain dan diproduksi menggunakan bahan kulit asli. Dengan kombinasi material kuningan yang dibentuk secara unik menggunakan sistem mekanika sederhana menjadikan produk ini memiliki keunikan tersendiri, baik dari segi produk maupun target pasarnya. Penggunaan material kuningan sebagai pengunci menampilkan kesan vintage yang berkelas.

(2) Produk tas kulit dengan pengunci mekanik fitur menghibur shutter kayu

Produk kedua yaitu tas kulit dengan pengunci mekanik shutter kayu, berbahan dasar kulit dan terdapat pengunci mekanik dibagian muka tas. Produk tas kulit ini berfungsi untuk menyimpan barang dengan fitur pengunci mekanik model shutter yang diputar dan dapat dimainkan sekaligus sebagai aksesoris gaya hidup. Tas ini didesain untuk wanita dengan model sling bag berukuran $24,5 \times 6 \times 14 \mathrm{~cm}$, dengan zipper dibagian atas dan lidah dibagian muka berukuran $24 \mathrm{~cm}$, berbahan dasar kulit dengan penguncian mekanik model shutter fungsional, berbahan kayu sungkai dengan fitur menghibur/dapat dimainkan. Terdapat satu kantung utama, satu tali selempang dan satu pengunci mekanik. Adapun komposisi garis dan/atau warna pada tas tersebut yaitu medium brown dengan bahan kulit aseli jenis nabati yang dipotong menggunakan CNC lasercut, dengan tampilan depan penguncian mekanik berwarna krem dengan diameter $11 \mathrm{~cm}$ yang dipotong menggunakan CNC router. Sedangkan untuk melubangi jahitan (stitch) digunakan lasercut yang kemudian dijahit secara manual.

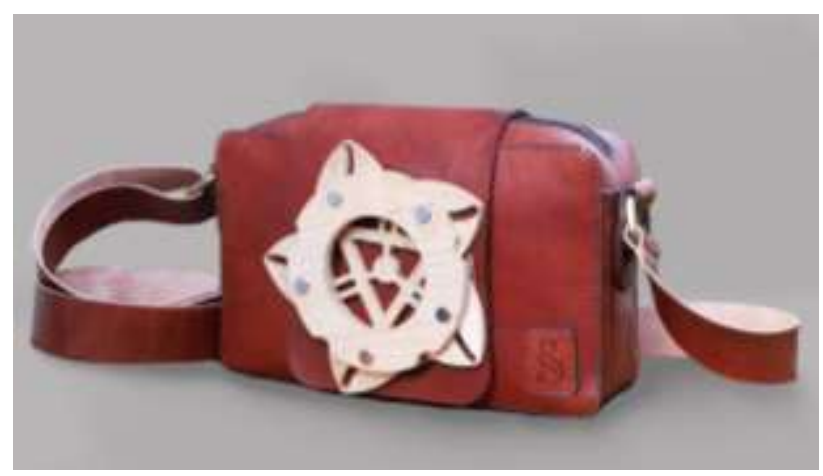

Gambar 31. Produk tas kulit dengan pengunci mekanik fitur menghibur shutter kayu

Produk ini memiliki keunggulan dari segi visual dan materialnya, keunikan kombinasi material dan juga bentuk iris yang multi fungsi menjadikan daya tarik yang kuat dan langka untuk pasar tertentu. Tas model selempang belum banyak menggunakan kombinasi material kayu dan kulit, produk ini dapat menjadi penggagas gaya baru dalam tas selempang.

(3) Produk tas kulit dengan fitur mekanik dekoratif menghibur kinetic sculpture

Produk ketiga yaitu tas kulit dengan mekanik dekoratif kinetic sculpture, berbahan dasar kulit dan terdapat mekanik dekoratif menghibur dibagian muka tas. Produk tas kulit ini berfungsi untuk menyimpan barang dengan fitur mekanik dekoratif menghibur, berefek ilusi optik yang dapat diputar dan dimainkan sekaligus sebagai aksesoris gaya 
hidup. Tas ini didesain untuk wanita, dengan bentuk bulat, model sling bag berdiameter $18 \mathrm{~cm}$, dengan zipper dibagian atas, berbahan dasar kulit dengan mekanik model kinetic sculpture yang dekoratif non-fungsional, berbahan kayu sungkai dengan fitur menghibur/dapat dimainkan. Terdapat satu kantung utama, satu tali selempang dan satu mekanik dekoratif. Adapun komposisi garis dan/atau warna pada tas tersebut yaitu medium brown dengan bahan kulit aseli jenis nabati yang dipotong menggunakan $\mathrm{CNC}$ lasercut, dengan tampilan depan mekanik bersifat dekoratif, model kinetic sculpture berwarna krem dengan diameter $18 \mathrm{~cm}$ yang dipotong menggunakan CNC router. Sedangkan untuk melubangi jahitan (stitch) digunakan lasercut yang kemudian dijahit secara manual.

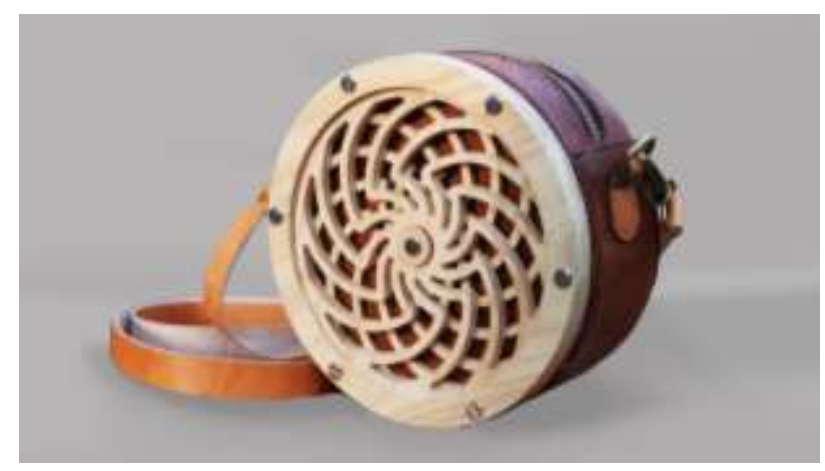

Gambar 32. Produk tas kulit dengan fitur mekanik dekoratif menghibur kinetic sculpture

Keunggulan produk ini didesain dan diproduksi menggunakan bahan kulit asli. Dengan kombinasi material kayu yang dibentuk secara unik menggunakan sistem mekanika sederhana dan menghibur, menjadikan produk ini memiliki keunikan tersendiri baik dari segi produk maupun target pasarnya. Pengaplikasian ilusi optik dan fitur yang dapat dimainkan merupakan kombinasi yang unik dan dapat menjadi daya tarik tersendiri bagi pengguna untuk pelepas stress dan bosan.

(4) Produk tas kulit dengan pengunci mekanik fitur menghibur rack and pinion kayu

Produk keempat yaitu tas kulit dengan pengunci mekanik rack and pinion kayu, berbahan dasar kulit dan terdapat pengunci mekanik dengan fitur menghibur dibagian muka tas. Produk tas kulit ini berfungsi untuk menyimpan barang dengan fitur pengunci mekanik rack and pinion yang diputar dan dapat dimainkan, sekaligus sebagai aksesoris gaya hidup. Tas ini didesain untuk pria dengan model messenger bag berukuran $28 \times 8 \times 17 \mathrm{~cm}$, dengan pegangan dibagian atas tas (handle), berbahan dasar kulit dengan penguncian mekanik model rack and pinion fungsional, dengan bentuk menyerupai setir kapal berdiameter $15 \mathrm{~cm}$ dan rel $4,5 \times 17,5 \mathrm{~cm}$, berbahan kayu sungkai dengan fitur menghibur/dapat dimainkan. Terdapat satu kantung utama, satu tali selempang, satu pegangan (handle) dan satu pengunci mekanik. Adapun komposisi garis dan/atau warna pada tas tersebut yaitu medium brown kombinasi tan, dengan bahan kulit aseli jenis nabati yang dipotong menggunakan CNC lasercut, dengan tampilan depan penguncian mekanik berwarna krem yang dipotong menggunakan CNC router. Sedangkan untuk melubangi jahitan (stitch) digunakan lasercut yang kemudian dijahit secara manual.

Menurut Don Norman (2004) dalam bukunya bahwa sisi emosional desain mungkin lebih penting untuk kesuksesan suatu produk daripada elemen praktisnya. Tesis dasarnya adalah bahwa produk yang menarik bekerja lebih baik. Dia berpendapat bahwa produk yang dirancang dengan indah membuat orang merasa baik, yang pada gilirannya menempatkan orang dalam kerangka berpikir terbuka untuk menjadi kreatif dan menemukan solusi untuk masalah yang mereka hadapi.

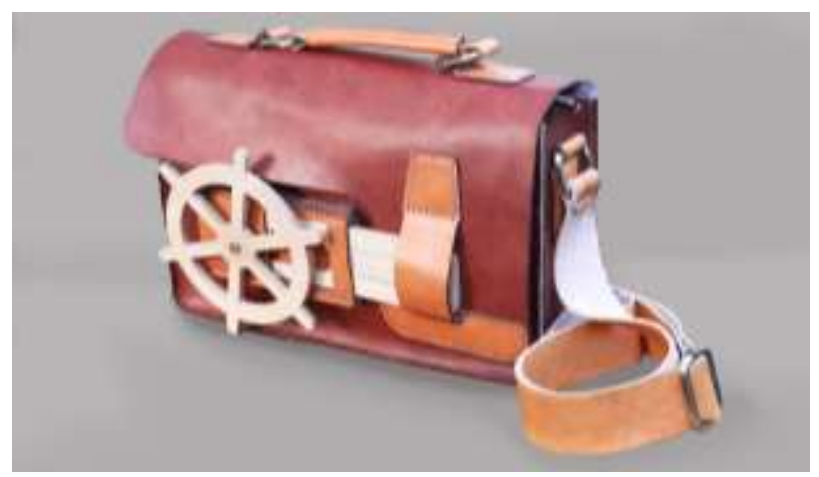

Gambar 33. Produk tas kulit dengan pengunci mekanik fitur menghibur rack and pinion kayu

Keunggulan produk ini didesain dan diproduksi menggunakan bahan kulit asli. Dengan kombinasi material kayu yang dibentuk secara unik menggunakan sistem mekanika sederhana dan fitur 
menghibur, menjadikan produk ini memiliki keunikan tersendiri baik dari segi produk maupun target pasarnya, mengingat material kayu belum banyak digunakan pada messenger bag, terlebih dipadukan dengan material kulit. Desain penguncinya pun sangat inovatif dan menghibur sehingga dapat digunakan sebagai pelepas stress dan bosan.

(5) Produk tas kulit dengan pengunci magnet dan fitur menghibur dekoratif tema kucing

Produk kelima yaitu tas kulit dengan pengunci magnet dan fitur menghibur dekoratif tema kucing, berbahan dasar kulit dan terdapat dekoratif dibagian muka tas. Produk tas kulit berfungsi untuk menyimpan barang dengan pengunci magnet dan dekorasi bertema kucing merupakan fitur menghibur yang dapat ditarik dan dimainkan sekaligus sebagai aksesoris gaya hidup. Tas ini didesain untuk wanita dengan model sling bag berukuran $15 \times 6 \times 20 \mathrm{~cm}$, dengan zipper dibagian atas dan lidah dibagian muka berukuran $14,5 \times 23 \mathrm{~cm}$, berbahan dasar kulit dengan pengunci magnet dan terdapat dekorasi berbentuk telinga dan kaki kucing sebagai fitur menghibur. Terdapat satu kantung utama, satu tali selempang, dua pengunci magnet dan dekorasi berbentuk telinga dan kaki kucing. Adapun komposisi garis dan/atau warna pada tas tersebut yaitu tan dan kombinasi medium brown, dengan bahan kulit aseli jenis nabati yang dipotong menggunakan $\mathrm{CNC}$ lasercut, dengan tampilan depan dekorasi berbentuk telinga dan kaki kucing dengan bahan yang sama. Sedangkan untuk melubangi jahitan (stitch) digunakan lasercut yang kemudian dijahit secara manual

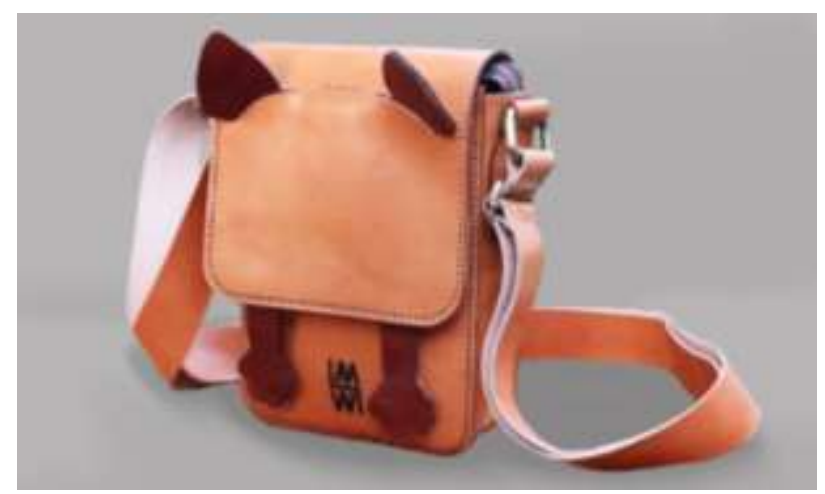

Gambar 34. Produk tas kulit dengan pengunci magnet dan fitur menghibur dekoratif tema kucing
Tas selempang dengan visual yang anekdotal selalu mendapat atensi khusus dari pengguna dengan gender wanita dan pecinta kucing. Penambahan konsep pengunci magnet dan objek elastis menjadikan produk ini memiliki fitur menghibur yaitu dapat dimainkan. Selain itu juga memberikan efek khusus seperti pada bagian muka tas produk memiliki telinga kucing yang sangat realistis ketika penutup tas diregangkan.

\section{Dokumentasi dan Publikasi}

Produk-produk final yang berhasil diproduksi kemudian didokumentasikan untuk arsip LPPM ITB. Produk-produk tersebut telah didaftarkan di DJKI Industri melalui LPik ITB pada bulan Agustus 2021. Sedangkan untuk publikasi terkait hasil kegiatan dilakukan melalui siaran pers yang dihadiri oleh beberapa media lokal berbeda di hari terakhir saat kegiatan berlangsung. Hal ini diharapkan mampu menginspirasi para pelaku usaha muda industri kreatif baik yang berada di wilayah Cirebon maupun di wilayah lainnya.

\section{Ucapan Terima Kasih}

Terima kasih kepada Lembaga Penelitian dan Pengabdian kepada Masyarakat ITB yang telah menyelenggarakan program pelatihan dan segenap pihak yang terlibat dalam proses keberjalanan program Pelatihan dan Pengembangan Desain Produk Berbasis Teknologi CNC bagi Lintas Komunitas Kreatif Muda Cirebon.

\section{KESIMPULAN DAN SARAN}

\section{Kesimpulan}

Pelatihan dan pengembangan yang telah selesai dilakukan diharapkan dapat menambah wawasan dan keterampilan peserta pelatihan, pengembangan usaha produk kulit yang lebih inovatif dan membuka peluang-peluang usaha baru bagi masyarakat daerah Cirebon dan sekitarnya dengan memanfaatkan teknologi CNC router maupun lasercut. Hasil pengembangan dan pembuatan desain produk yang telah dibuat, sedikitnya terdapat lima desain produk telah didaftarkan di DJKI melalui LPiK ITB. Kegiatan acara dan produk mekanika dengan fitur menghibur telah dipublikasikan melalui siaran pers yang diliput oleh beberapa media cetak maupun digital dan kanal 
media sosial LPPM ITB. Proses publikasi dilakukan dalam upaya menginspirasi para pengusaha untuk mengembangkan usahanya melalui pendekatan kombinasi material; dalam hal ini material kulit, kayu dan kuningan, serta dalam memanfaatkan teknologi CNC yang mulai berkembang dan banyak digunakan oleh para pengrajin. Dalam rangka memperkenalkan produk kulit berbasis mekanik dengan fitur menghibur dan menginspirasi banyak pihak, produk-produk dari hasil pelatihan dan pengembangan ini akan diikutsertakan dalam pameran wirausaha berskala lokal di kota-kota besar di Indonesia.

\section{Saran}

Perkembangan dunia kerajinan cukup pesat, begitupun kebutuhan manusia. Pengembangan produk harus selalu dilakukan untuk menjawab kebutuhan manusia kedepannya. Saran untuk kegiatan pengabdian masyarakat selanjutnya adalah coba kembangkan potensi sekitar dengan pertimbangan tantangan masa depan.

\section{DAFTAR REFERENSI}

Blijlevens, J., Creusen, M. E. H., \& Schoormans, J. P. L. (2009). How consumers perceive product appearance: The identification of three product appearance attributes. International Journal of Design, 3(3), 27-35.

Dalgic, Tevfik. (1998). Niche Marketing Principles. Journal of Segmentation in Marketing. 2. 10.1300/J142v02n01_02.

Hidayat, Yuniawan, and Tutik Susilowati, editors. (2016) Panduan pendirian usaha [jenis usaha]. Indonesia, Badan Ekonomi Kreatif Indonesia. Diunduh dari: www.kemenparekraf.go.id/asset_admin/as sets/uploads/media/pdf/media_158982924 8_Buku_Panduan_Tas_Kulit.pdf.

Lynch, Mike. (1997, January). Key CNC Concept \#1-The Fundamentals Of CNC. Modern Machine Shop. Diunduh dari: www.mmsonline.com/articles/key-cncconcept-1 the-fundamentals-of-cnc.

Fontana, R., and Nesta, L. (2009). Product innovation and survival in a high-tech industry. Review of Industrial Organization, 34(4), 287-306.

Foster, M. K. (2019). Design Thinking: A Creative Approach to Problem Solving.
Management Teaching Review, 6(2), 123140. https://doi.org/10.1177/2379298119871468

Marius, Paun \& Doroftei, A.A. \& Tudor, G.A. \& Moldovan, I.. (2018). CNC Router with Screw-Nut Transmissions. The Scientific Bulletin of Electrical Engineering Faculty. 18. 40-42. 10.1515/sbeef-2017-0032.

Nagaraj, Varun \& Lyytinen, Kalle \& Gaskin, James. (2020). Team Design Thinking, Product Innovativeness, and the Moderating Role of Problem Unfamiliarity. Journal of Product Innovation Management. 37. 10.1111/jpim.12528.

Parrish, David. (2019, Dec). Creative Industries Definitions. David Parrish. Diunduh dari: www.davidparrish.com/creativeindustries-definitions.

Pressman, Andrew. (2018). Design Thinking: A Guide To Creative Problem Solving For Everyone. 10.4324/9781315561936.

P. Radhakrishnan, Computer numerical control machines and computer aided manufacture, New Academic Science, 2014.

Silinevica, Irena, et al. (2016). Research Of The New Product Development Process. Latgale National Economy Research, vol. 1, no. 8, p. 116. doi:10.17770/lner2016vol1.8.1850.

Situmorang, James R. (2017). Pemasaran Relung (Niche Market) sebagai Strategi Membidik Pasar yang Lebih Kecil. vol. 13, no. 2.

Zahra, S. A., \& Chandler, A. D. (1999). [Review of The Dynamic Firm: The Role of Technology, Strategy, Organization, and Regions, by $\mathrm{P}$. Hagström \& Ö. Sölvell]. The Academy of Management Review, 24(4), 861-863. 